\title{
Discussion on Teaching Reform of "Traditional Landscape Architecture Design" Course in Applied Universities
}

\author{
Zhang Zhiwei ${ }^{1, *}$, Que $\mathrm{Yi}^{1}$, Tang Haiyan ${ }^{1}$, and Zhang Zhiwei ${ }^{1}$ \\ ${ }^{1}$ City College of Science Technology, Chongqing University, 402167, China
}

\begin{abstract}
Traditional garden design is considered as the main course of landscape architecture. Through the teaching reform of this course, students can learn the design principles and methods of landscape design and combine classroom theoretical teaching with practical teaching. In view of the characteristics of application-oriented universities, this paper improves the teaching quality of traditional landscape architecture design course through the discussion-based teaching method.
\end{abstract}

\section{Problems existing in the teaching of traditional garden architecture design course}

\subsection{Content need to improve}

The content of the teaching book is not updated by time and hard for students to access the new knowledge and bring the weakness in their self-learning.

In terms of teaching content, as it is targeted the industry and focused on the major with a single knowledge structure and slow update of teaching content. Therefore, it is difficult for students to choose which subject that they want to learn based on their own needs and interests.

\subsection{Teaching methods need to improve}

Because of the teaching methods are poor and single which make student's less interest and attention to the class.

From the instructor's point of view, there are too many students to be guided.In order to complete the teaching task, the course is setting as the same standard for all students to complete.It is common to see the fact that teachers are failed to highlight each student's characteristics about the subject.

From the student's point of view, as they are not able to get the specific guidance from the teacher and even the targeted guidance time is shorter which students will not have enough time to learn and practice.

\subsection{Lack of innovation}

The lack of innovation in teaching and less emphases the cultivation of application which are easily stop the development of student's characteristics and innovative thinking.

The classroom teaching which the teacher usually plays the main role in delivering the knowledge to students neglect the cultivation and training of students' creative thinking mode. The classroom atmosphere is dull, which causes the student to lack the quality which questions. The study enthusiasm is passivated, which causes the thought to block.The thought activity degree is suffocated, which causes the innovation spirit and the innovation consciousness to be weakened.

\subsection{Lack scientific nature}

The course examination method lacks scientific nature, the student's enthusiasm has not been mobilized, the teaching effect is poor.

The teaching evaluation method of traditional landscape architecture design still follows the traditional evaluation method by using the forms of attendance checking, classroom discussion, design homework and so on as the reference for given scores. This kind of evaluation method is classified and evaluated based on students' learning behavior. In fact, a more scientific and reasonable evaluation method should be classified based on students' learning ability.

\section{Exploration and practice of new teaching methods and means}

\subsection{Scientific and reasonable implementation plan}

The scientific and reasonable implementation plan is formulated through exploratory teaching and the

\footnotetext{
* Corresponding author: xiaowei988211@163.com
} 
teaching content is optimized. It is more conducive to the cultivation of applied talents.

It is the premise of the implementation of seminarbased teaching to formulate research topics for teaching content.The teaching content of traditional garden architecture involves geology, geomorphology, hydrology, architecture, art, culture, ecology, environment and other fields. The interaction between of them is obvious, and many problems are complicated. With the continuous advancement of the times, knowledge has been updated more, these can't be updated in the textbooks. Teachers should constantly update the new teaching content while teaching the content of the teaching materials, so that students can master the most cutting-edge knowledge of the subject. There are two courses in the garden architecture design class in the 2016-level training program. The curriculum of the garden architecture design should be sorted out from the whole, and the teaching tasks of each course should be clarified, so that the curriculum system of the landscape architecture design course is more systematic and perfect.(shown in Table 1).

According to the traditional landscape architecture design of teaching tasks, which could cultivate students' active learning ability and application ability. It is also useful to the traditional landscape architecture design of systematic arrangement, and enrich the teaching content.The landscape architecture design with discussion of teaching reform ideas and goals adapted in addition to the professional talent training plan and course syllabus.Refer to the course characteristics and the existing teaching resources are conducive to the discussion teaching concrete implementation plan.(shown in Table 2).

Table 1. Description of the teaching tasks of the 2016 level garden architecture design courses.

\begin{tabular}{|c|c|c|c|}
\hline $\begin{array}{c}\text { Course } \\
\text { Title }\end{array}$ & Semester & Cycle & Teaching task \\
\hline $\begin{array}{l}\text { Traditional } \\
\text { garden } \\
\text { architecture } \\
\text { design }\end{array}$ & 5 & 48 & $\begin{array}{l}\text { It introduces the } \\
\text { classification and } \\
\text { individual } \\
\text { characteristics of } \\
\text { traditional Chinese } \\
\text { garden architecture } \\
\text { (mainly pavilions, } \\
\text { terraces, buildings, } \\
\text { halls, halls, galleries, } \\
\text { pavilions, etc.). To } \\
\text { enable students to do } \\
\text { simple traditional } \\
\text { garden architecture } \\
\text { design, to be able to } \\
\text { carry out architectural } \\
\text { selection and layout } \\
\text { in garden engineering }\end{array}$ \\
\hline $\begin{array}{l}\text { Modern } \\
\text { garden } \\
\text { architecture } \\
\text { design }\end{array}$ & 6 & 48 & $\begin{array}{l}\text { To enable students to } \\
\text { master the basic } \\
\text { principles and } \\
\text { methods of modern } \\
\text { garden architecture }\end{array}$ \\
\hline
\end{tabular}

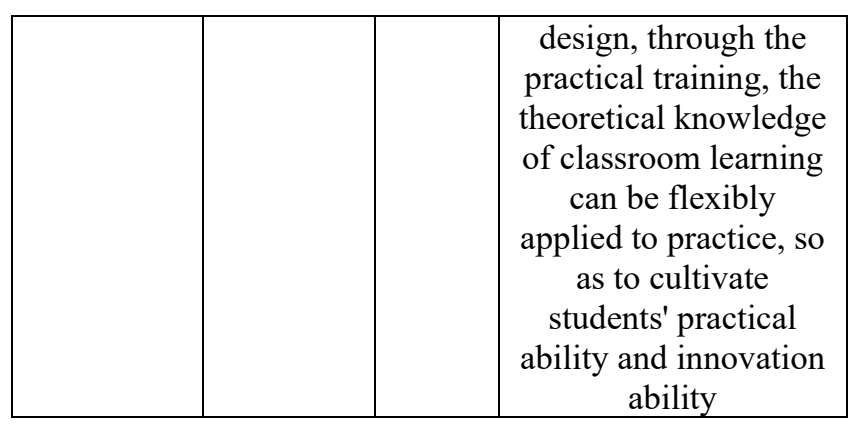

Table 2. Teaching content of traditional garden architecture design in 2016

\begin{tabular}{|c|c|c|}
\hline \multirow[t]{2}{*}{ Chapter } & $\begin{array}{c}\text { Period } \\
\text { distribution } \\
\end{array}$ & \multirow[t]{2}{*}{ Instructions } \\
\hline & Theory & \\
\hline $\begin{array}{l}\text { The first } \\
\text { chapter } \\
\text { Overview of } \\
\text { landscape } \\
\text { architecture } \\
\end{array}$ & 8 & $\begin{array}{l}\text { It mainly introduces } \\
\text { students to the concept of } \\
\text { garden architecture and } \\
\text { the function of garden } \\
\text { architecture. }\end{array}$ \\
\hline $\begin{array}{l}\text { The second } \\
\text { chapter } \\
\text { Characteristics } \\
\text { of Traditional } \\
\text { landscape } \\
\text { architecture } \\
\end{array}$ & 8 & $\begin{array}{l}\text { The characteristics of } \\
\text { traditional garden } \\
\text { architecture, the space } \\
\text { layout of traditional } \\
\text { garden architecture and its } \\
\text { treatment. }\end{array}$ \\
\hline $\begin{array}{l}\text { The third } \\
\text { chapter } \\
\text { Monomer } \\
\text { design of } \\
\text { Traditional } \\
\text { landscape } \\
\text { architecture }\end{array}$ & 12 & $\begin{array}{l}\text { The main points of design } \\
\text { of different types of } \\
\text { traditional garden } \\
\text { buildings are taught, and } \\
\text { the cases of new design } \\
\text { methods of traditional } \\
\text { garden buildings are } \\
\text { analyzed at present. }\end{array}$ \\
\hline $\begin{array}{l}\text { The fourth } \\
\text { chapter } \\
\text { Practical } \\
\text { training in the } \\
\text { design of } \\
\text { Traditional } \\
\text { landscape } \\
\text { architecture }\end{array}$ & 20 & $\begin{array}{l}\text { Through practical project } \\
\text { case analysis, students can } \\
\text { master the basic methods } \\
\text { and design procedures of } \\
\text { traditional garden } \\
\text { architecture design }\end{array}$ \\
\hline
\end{tabular}

\subsection{Diversified teaching method}

By adopting the deliberative teaching method, the teaching methods are more diversified.

Discussion-based teaching is a teaching mode which aims to cultivating students' independent learning ability and innovative spirit by adopting various teaching methods and methods under the guidance of teachers. In the past, Teachers mainly focused on theoretical teaching. Such as pictures, videos, or PPT, were used to assist teaching, it was difficult for teachers and students to discuss and communicate in the classroom, so that students' enthusiasm and initiative were insufficient, thinking and research. The ability to solve problems is not cultivated, and the teaching effect is not good. According to the characteristics of the course and the basic contents of the chapter of traditional garden architecture design, the research topic can be determined by combining the actual project and frontier research hot 
spots of the subject. For example, according to the course content of landscape architecture layout form, the relationship between landscape architecture and landscape architecture can be used as the basic summative topic for discussion. Students are required to refer to relevant references to make a summary, focusing on cultivating students' thinking ability and language expression ability to analyze and summarize. According to the course content of building design for landscape architecture, the design of landscape architecture can be determined as the form of layout of landscape architecture as the research topic of expansion analysis. According to the course content of traditional garden architecture design, the applied research of Chinese classical garden architecture design in the new period can be regarded as the research topic of the frontier of the subject, and the design is carried out with the actual project,focusing on cultivating students' innovative ability to grasp the academic frontier and conduct academic research. Through this knowledge exploration process, students are trained to analyze problem-solving skills, design abilities, language expression skills and teamwork abilities, so that they can truly "learn to learn" and thus improve their overall quality. This is the most prominent and fundamental feature of implementing seminar-based teaching.

\subsection{Seminar-based teaching methods}

The seminar-based teaching methods which are used in teaching process can cultivate students' ability of innovation and practice.

The construction of the traditional garden architecture design course discussion mode should be based on the teacher-led,student-centered principle which enable students to give full play for their enthusiasm, initiative and creative role so that it can cultivate students' innovative and practical ability. The teaching pattern of traditional landscape architecture design, specifically it can divide into four steps, that is teachers assign tasks -- pre-class preparation -classroom teaching -- evaluation and summary. The essence of the such teaching model is based on the problems study through collecting data , summary, classroom discussion, analysis, evaluation and summary so that it can stimulate students' interest in learning and enthusiasm, arouse students' desire for exploration, and then enable students to learn creatively, ultimately optimize classroom teaching, improve teaching quality, and achieve application-oriented talent training goals. Seminar-based teaching is a problem-centered teaching method. By creating a problem situation by teachers, teachers and students can jointly find information, research, discussion, practice, and exploration, and then propose solutions to problems so that students can acquire knowledge and skills.

Transforming the role of teachers, clarifying the subjective status of students, giving full play to students, and the potential of independent inquiry and learning is the key to the effective implementation of researchbased teaching. Accurately locating the roles and relationships of teachers and students is a prerequisite for implementing seminar-based teaching. Through the discussion-based teaching reform, this paper explores the new orientation of the roles of teachers and students, clarifies the subjective status of students, and realizes the transformation of the roles of teachers and students. Teachers should follow the principle of "giving the fish better than giving it to fish", from "teaching" to "guidance", guiding students to collect data, formulate plans, design experiments, and explore rules through various channels. Guide students to find answers in their own learning, emphasizing the process of student inquiry and not the result. Training students to learn from "want to learn " to "learn what it is "then "know how to learn '.

\subsection{Reform the score assessment method}

Reform the score assessment method to ensure the course examination more reasonable so that it can guarantee for creating better teaching conditions.

It is very necessary that a set of scientific assessment methods be established to students. This method can stimulate students' enthusiasm, initiative and creativity. In ordre to cultivate students' practical and innovative ability, we should develop students' personality characteristics.

According to the characteristics of seminar teaching, which the students'performance assessment of the traditional architectural design course can apply the diversified assessment method that are combining learning attitude, research materials, group report, lecture notes, special report, class discussion, daily work completion and final design work to assess the student's grade. The main body of performance evaluation includes teacher evaluation, student mutual evaluation and self-evaluation etc.

\section{Phased results and problems.}

\subsection{Phased results}

The theme of the design course assignment book is determined as the service building design. The teaching link include research the information-field researchresearch report - one grass design — two grass design three grass design - complete the final designevaluation link. Through the communication with the students and the discussion each other, they can carried out the theoretical knowledge assessment . They can also evaluate the design results through the research report(As shown in Figure 1.1,1.2). 


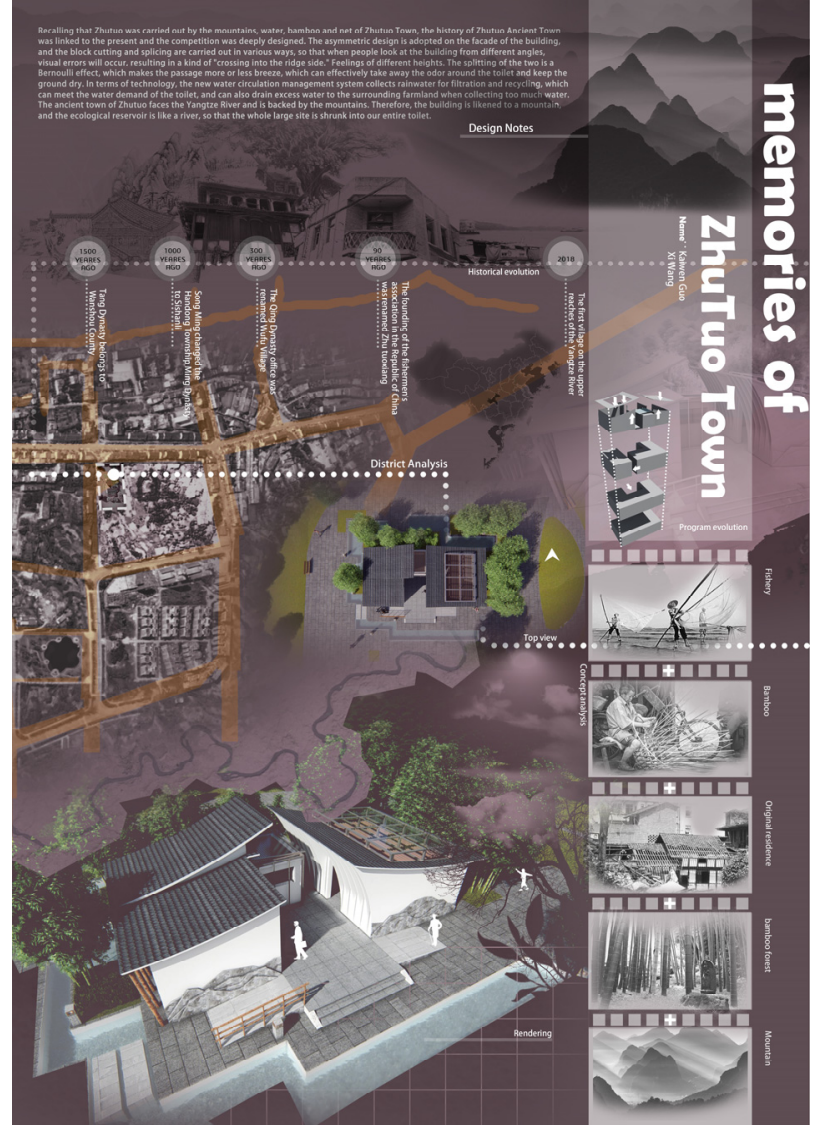

Figure 1.1 Public toilet building design 1

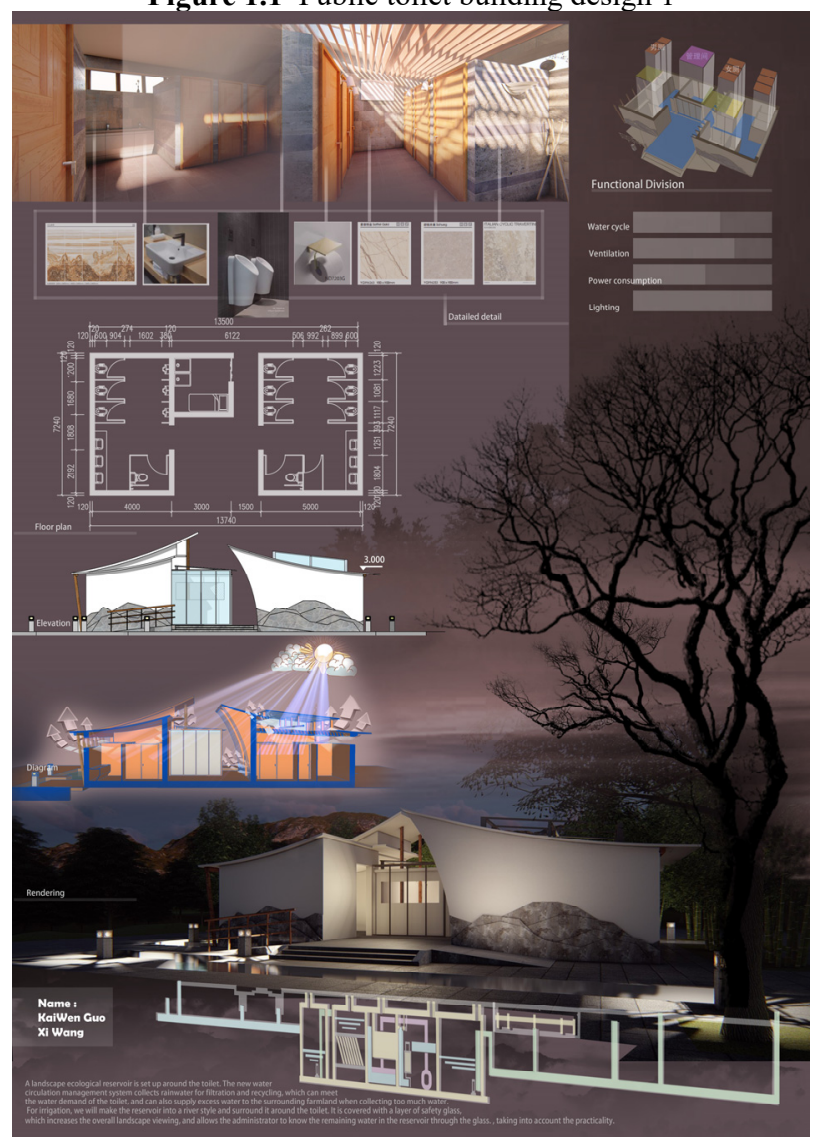

Figure 1.2 Public toilet building design 2
The problems encountered in the implementation process were mainly that the students did not study the subject of Housing Architecture, so the knowledge of the building is very scarce and the implementation of the course has a great influence. The design theme of this course is the design of the Tearoom, which is the category of garden architecture. The knowledge points of the building must be mastered.

In response to this problem, The basic knowledge of the building was explained in class. The students were able to master the knowledge of the building before designing, which made the latter design handy. The knowledge of architecture is mainly divided into: Chinese and foreign architectural history, The architectural design of elements, and Building construction. The student's response was better, from doubt to familiarity. The assessment method is mainly added to the usual grades, and the assessment of the building part is completed through questions and exchanges in class.

\section{References}

1. Shu, M. H. \& Xing, Z. (2007). Modern "urban portal" resolves. Huazhong Architecture, 25(10), 4446.

2. Lu, F. (2013). Study on regional urban design. New Architecture, (3), 18-21.

3. Yan, A. J., Wan, Y. M. \& Chen,. M. C. (2013). Discussion on the design of landscape urban portal. Modern Urban Research, (3), 60-63.

4. Tan, X. (2003). Harmony of history, nature and environment: urban environment art. Shenyang: Liaoning Science and Technology Press.

5. Yu, K. J., \& Pang, W. (2002). Understanding design: reuse of industrial site in the design of Qijiang Park of Zhongshan City. Architectural Journal, (8), 47-53.

6. $\mathrm{Wu}, \mathrm{S}$. (2001). Language of post-modernism in modern gardens. Journal of Suzhou Institute of Silk Textile Technology, 21(2), 174-177.

7. Zhang, G. H., Zhou, L. \& Huang, K. P. (2011). The development trend of urban space structure under construction of high-speed traffic network: From "center node" to "portal node". Urban Planning Forum, 195(3), 27-32.

8. Zhao, W. Y. (2001). Significance of modern architectural aesthetics. Nanjing: Southeast University.

\subsection{Problems and Countermeasures}

